\title{
Fuel Research
}

$\mathrm{T}$ HE report of the Fuel Research Board* for the year ending March 31, 1935, differs from its predecessors in the emphasis given to problems arising from the preparation of coal for sale. This follows naturally on the changes taking place at British collieries, where increasing proportjons of coal are obtained by mechanical methods, and are also subjected to various cleaning processes. Again, consumers become more reluctant to pay a premium for size. Apart from the open fire, there are few uses for large lump coal. It is the modern tendency to employ automatic mechanical methods of firing boilers, furnaces and producers, and for such uses coal must be small in size and uniformly graded. Formerly, small coal was often deliberately rejected by the use of forks for loading underground. To-day collieries are increasingly finding it necessary to break lump coal to supply the demand for small fuel, and this has brought into prominence many chemical and physical problems previously unknown. The best methods of breaking to preserve sizes and avoid the production of dust have been investigated. Coals broken and graded suitably at the colliery were found to suffer little further degradation in normal transport to the consumer.

The development of schemes for coal marketing has disclosed the need and opportunity to reduce the number of sizes of marketable coal. The Board is collaborating with the Midland Institute of Mining Engineers and the South and West Yorkshire Coal Owners in an attempt to do this. It was found, in this area, that no less than 106 different size grades of coal below 3 in. size were being marketed; and

* Department of Scientific and Industrial Research. Report of the Fuel Research Board for the Year ended 31st March, 1936; with Report of the Director of Fuel Research. Pp. $x+217$. (London: Report of the Director of Fuel Resea
H.M. Stationery Oflice, 1936.) 48 . net. yet seventy per cent of the coal fell within 15 size grades. With slight adjustment of the size mesh, these 15 grades would cover ninety-five per cent of the tonnage. It is difficult to see any technical reason for marketing coal in so many sizes, and there must be advantage in selling to reduce the number.

Considerable attention has been given to the question of mixing or blending coal from different seams. It is often forgotten that the supply of good coking coal is limited. The problem of blending coals, which though unsuitable alone, give good coke when carbonized after blending with others, is receiving increasing attention.

The supply of active carbon suitable for respirators and gas masks is obviously a very important matter. Some materials on carbonization yield an active residue, but it is known that less active carbon can be activated by gasification with steam. The report records that it has been found possible at the Fuel Research Station to carbonize selected coals, of the durain type, and treat the coke with steam at a high temperature to obtain an active carbon nearly as good as the best obtainable and at a considerably lower cost. The importance of this observation needs no emphasis. The cost of active carbon is a limiting factor in processes for recovery of vapours.

Systematic work on the hydrogenation of coal and tar oils has been continued. Attempts to prepare first-class lubricants from coal tar oils have not been successful--possibly because the molecular structure of these hydrocarbons is unsuitable. It now appears that the most hopeful line is to synthesize hydrocarbons from carbon monoxide and hydrogen, and experiments in this direction have been initiated.

The report touches most aspects of national fuel problems and may be commended to those who seek a conspectus of the current position. H. J. H.

\section{Twenty-fifth Anniversary of Laue's Diagrams}

$I_{\mathrm{B}}^{\mathrm{T}}$ has been a pleasure to men of science in Great 1 Britain to see the growing interest taken and progress made in science in India. The rapidly increasing list of original investigators, and the importance of many of their papers, contributed not only to their own institutions but also to learned societies in Great Britain, are a source of sincere gratification. Forty years ago (1896) I was present at the opening of the completed Indian Institute in Oxford, by the exViceroy, Lord Dufferin, accompanied by Mr. Asquith (afterwards Prime Minister and Lord Oxford), who made a remarkable speech in welcoming our Indian co-subjects of the British Crown to partake of the best of our educational facilities. The fraternal lead then given has borne such wonderful fruit that India itself is now providing all that is needful, without any longer feeling the necessity of expatriating its sons to Europe for their higher education.

These facts are remarkably illustrated at the moment by the appearance of a special number of
Current Science, a monthly journal devoted to science published at Bangalore, with the aid of thirty natives of India. This special number is devoted entirely to marking the twenty-fifth anniversary of the discovery by Laue of the diffraction of $\mathrm{X}$-rays by erystals, and to the review of the years of intense research into crystal structure which have followed. It contains a dozen articles by the leaders in this work, the first being by Prof. Max von Laue himself, with his portrait as frontispiece. Succeeding articles are by Sir William and Prof. W. L. Bragg, Prof. P. P. Ewald, Prof. M. Siegbahn, Prof. A. Sommerfeld, Dr. L. Pauling, Prof. C. G. Darwin, Prof. H. Mark, Prof. J. A. Prins, Dr. S. K. Allison, Prof. H. A. Kramers, and Dr. S. Rama Swamy ; an introduction is also contributed by Sir C. V. Raman. The mere fact that such a remarkable jubilee 'Festschrift', celebrating Laue's epoch-making discovery, should be organized by our Indian scientific brethren, speaks volumes for the advance of science in India. 